\title{
Student Experiences of a Blended Learning Environment
}

\author{
Jase Moussa-Inaty \\ Zayed University \\ Abu Dhabi, The United Arab Emirates
}

\begin{abstract}
Higher education institutions are showing increased interest in innovative teaching and learning approaches. One such approach is related to blended learning which is a combination of both face-to-face and online delivery. This study aims to determine students' feelings towards a blended learning class. The study utilized a qualitative method by employing text analysis of student's reflective journals. Three categories emerged, namely; F2F Preference, Blended Preference, and Converted Preference. The results showed that majority of the students preferred F2F classes instead of the blended classes. A significant finding of this study was that despite a high percentage of students who preferred a F2F learning experience almost all the students mentioned that they enjoyed the blended learning experience and would either take another blended course or recommend the same course to a friend. Educational implications and future research direction are also discussed.
\end{abstract}

Keywords: blended learning; face-2-face; online learning; learning environment; learning preferences.

\section{Introduction}

Providing students with a variety of learning approaches offers a competitive edge for any higher education institute. When instructors provide lecture type or face-to-face (F2F) experiences, there is risk of students experiencing cognitive overload especially if presented materials are crowded with information that is redundant (Moussa-Inaty \& Atallah, 2012; Moussa-Inaty, Ayres, \& Sweller, 2012). Blended learning may offer a positive contribution and may reduce the risk of cognitive overload hence provide an opportunity for students to engage in a variety of delivery modes of instruction where F2F is not the only form of learning. In a blended class, students engage in various targeted tasks through a range of technological tools. Indeed, information and communication technologies have become a fundamental part of the educational system and learning in countries worldwide (Matukhin \& Evseeva, 2014). 
In defining blended learning, Graham (2013) speaks of blended learning systems, while drawing on a systems theory perspective. According to Graham (2013) blended learning involves a combination of both face-to-face and online instruction. Others have identified various models of blended learning while also stressing that blended involves online delivery of content and instruction in addition to face-to-face delivery (Stalker \& Horn, 2012). It has been argued that blended learning can help in dealing with possible ineffective uses of learning time through more virtual and interactive lectures and activities (Bonk \& Graham, 2012; Thorne, 2003).

Research has demonstrated a positive perception of the influence of blended learning on student engagement (Atallah \& Moussa-Inaty, 2012; Holley \& Oliver, 2010). A blended learning class may provide students a certain amount of freedom allowing students to learn at their own pace (Singh, 2003). Blended learning also offers a variety of learning experiences that may match individual learning preferences. This, in turn, may positively impact students' academic achievement. It is important, however, to note that for successful blended learning, students must be effectively engaged (Gradel \& Edson, 2011). Hege (2011) argues for the need to have an engaged community that takes into consideration elements such as course design, social presence, tailored assignments, learner expectations, in addition to a continued interaction between course materials, learners and the instructor for a successful blended delivery of instruction to occur. Blended learning is capable of offering solutions when it comes to issues related to accessibility and cost. As stressed by Dziuban, Hartman and Molskal (2004), blended learning in higher education is an evolving phenomenon that addresses issues such as access, cost, efficiency and timely degree completion. Singh (2003) further asserts that combining different delivery modes, such as F2F and online, can optimize the deployment of cost and time in addition to enhancing the development of learning programs. Accordingly, more and more higher education institutions are showing increased interest in such innovative teaching and learning approaches (Lim, Morris \& Kupritz, 2014). Recent studies have highlighted the importance of student's previous learning experiences when looking at student satisfaction on blended learning (e.g. Zhu, 2017). As universities witness the emergence of new technologies that offer unconventional approaches to teaching and learning, there is a need to offer classes that are unconventional in nature as well. In the context of the UAE, recent research has investigated student readiness to engage in e-learning, results showing that students expressed willingness to enroll in elearning courses (Atallah \& Moussa-Inaty, 2013). In fact, students indicated that they would prefer a blended learning approach because it involved both online and F2F learning experiences (Atallah \& Moussa-Inaty, 2013). Though one can conclude that students had positive attitudes towards e-learning, one cannot assume that similar attitudes or feelings will be similar when enrolled in a blended learning class and no research in the UAE has been conducted to examine how students feel about blended classes they are enrolled in. The research presented in this paper, therefore, aims to present students' experiences of a blended learning course offered at a federal institution in the UAE. Specifically, the research attempts to analyze students' reflective journals of their own blended learning experience. This research is necessary as it allows for 
more informed decisions related to the adoption of e-learning, specifically blended learning, as an alternative mode of instruction. This study also provides an opportunity for students to voice their opinion regarding a blended learning experience. Furthermore, this type of analysis can help in identifying the developing feelings of students enrolled in blended classes that can in turn be an important finding as far as future enrolment in blended classes is concerned.

The following two research questions are addressed in this paper: (1) How did students feel about their blended learning experience? (2) What difficulties/challenges did students experience during their blended learning experience?

\section{Blended Learning in the United Arab Emirates}

Some have argued that blended learning is ill-defined and inconsistently used (Olivier \& Trigwell, 2005), still there is enough evidence to support the benefits of blended learning (Bower, Kennedy, Dalgarno, Lee, \& Kenney, 2015; Buran \& Evseeva, 2015; El Alfy, 2017; Nazarenko, 2015) which explains why there is a push towards e-learning and blended learning in the Gulf region (Biju, 2010). Despite this, barriers towards e-learning and technology exist. For example, Schoepp (2005) investigated what UAE faculty members perceived as barriers as they attempted to integrate technology into their teaching - results indicating strongest barriers were faculty being unsure as to how to integrate technology effectively. Other barriers included lack of sufficient training, technical support and time constraints. Several other e-learning barriers in the UAE have been identified in the literature such as preference to talk to the teacher and preference of e-learning in one's own language, to name a few (Vrazalic, MacGregor, Behl, \& Fitzgerald, 2009). More recently, in a small-scale preliminary study exploring graduate students learning experiences of a blended learning class at a federal institute in the UAE, students commented that they had concerns about technical failures and a lack of F2F communication, which in their opinion, allowed for a smoother communication process between the professor and students (Moussa-Inaty, 2012). Moussa-Inaty (2012) stressed that while most students preferred a conventional F2F mode of instruction, some were willing to engage in blended learning provided that classes start with F2F sessions followed by online sessions and that there was on-going supervision and mentoring during both F2F and online sessions. Similar results were demonstrated in the Al-Mekhlafi (2004) study showing that many UAE colleges prefer merging two modes of instruction-online teaching and onsite (F2F) teaching. In a study by Tubaishat and Lansari (2011), UAE learners also showed to prefer F2F learning.

The UAE studies presented in the literature are mainly preliminary in nature and do not report on blended learning experiences. It is evident that there is a need to seek students' and faculty attitudes toward e-learning. A closer look at current and first time blended learning experiences by students is also crucial. In doing so, information can be gained especially when it comes to developing, evaluating, and running current and future blended learning classes. 


\section{Methodology}

The study adopted a qualitative method employing text analysis of student's online reflective journals to investigate student feelings towards a blended learning experience. Journal writing as a method which involves analyzing, criticizing, evaluating, and identifying challenges has gained significant prominence in the literature (Daniel, 1992). Journal writing involves the stimulation of thoughts - allowing one to look into oneself, one's feelings, and one's actions (Wood, 2012). In addition to providing a platform from which instructional designers can work from when designing and running blended learning classes, it was anticipated that by looking at student's reflective journals, students were provided a voice to express themselves and a way of conversing with themselves as they attempted to make sense of their blended learning experience.

\section{Participants}

The study was conducted at a federal university in the UAE with seventy-two undergraduate female Emirati students who were enrolled in an education class on human growth and development. There were no male students in this class because of the structure of the university (an all-female campus), hence the participants were only females. The education class was not only open to education students and so for most the students, this class was an elective. As such, the participants were from the mixed majors offered at the university; namely, Arts and Creative Enterprises, Business, Communication and Media Sciences, Education, Sustainability Sciences and Humanities, and Technological Innovation. Though the language of instruction was in English, the participants' native language was Arabic, but they all were able to read, write, and speak in English. The participants were familiar with some e-learning tools such as Blackboard and this was their first blended learning experience. The mean age for the participants was 20.5 years. Ages ranged from 19 to 22 .

\section{Procedure}

Technical skills and familiarity with the communication platform is crucial prior to the start of the blended learning experience and warrants consideration (White, Ramirez, Smith, \& Plonowski, 2010). Accordingly, all students enrolled in the blended learning class received various supporting and guiding tools at the start of classes, which were F2F in order to help support their novel learning experience. For example, a detailed course guide that included screenshots and various images was provided to show how students could navigate and effectively use Blackboard for (a) content related materials, and (b) assessment related materials. Blackboard was used as the basic platform for the various online and virtual activities such as discussion board. By also using Blackboard as a platform for journal entry, the students were encouraged to write reflective journals and although they were encouraged to contribute to their journal at least once a month, they were allowed to add entries whenever they felt they had something to write or share. Students were reminded that the journal was about them, that is their feelings, thoughts, views, and reactions towards their blended learning experience. 


\section{Instrument and Data Analysis}

In order to address the two research questions, students enrolled in a blended class were asked to keep a reflective journal about their blended learning experience from the start until the end of the semester. Therefore, the data used for this study was drawn from the students' journal entries on Blackboard. The participant's reflective journals were analysed using constant comparative analysis or the grounded theory approach (Glaser \& Strauss, 1967; Strauss \& Corbin, 1990). Based on the grounded theory approach, the researcher does not impose categories; rather, these categories for theorizing the data emerge from respondents' answers in the written reflective journals in the case of the current study. Categories were generated by frequently comparing new statements with previously reviewed statement. This process of categorical coding allowed the researcher to establish credibility of the findings.

\section{Results and Discussion}

This section will present a summary of the results of the qualitative data. Results are organized by research questions and are displayed by categories. It is important to note that the majority of the students uploaded an average of three journal entries throughout the semester.

\section{Research question 1: How did students feel about their blended learning experience?}

The outcome of the data analysis revealed the emergence of three major categories in relation to how students felt towards their blended learning experience. The first theme was F2F Preference and this referred to individuals who preferred F2F class sessions throughout the blended learning experience. The second category that emerged was Blended Preference which referred to individuals who had positive feelings towards the blended learning experience preferring a mix of both F2F and online sessions. The last category to have emerged was Converted Preference and this category referred to individuals who preferred one specific learning approach at the beginning of the semester, and then had a different or converted learning approach preference towards the end of the semester.

The results demonstrated that after a blended learning experience, a large number of students stated that they preferred a F2F learning experience $(43.5 \%)$ and this was followed by a group of students who stressed that they enjoyed the blended learning experience (37\%) more than a conventional F2F learning experience. A number of students (19.5\%) had converted feelings. Sample student journal extracts can be seen in Table 1 below.

Table 1: Students responses on blended learning experience

\begin{tabular}{|l|l|l|}
\hline Category & Item & Sample journal extracts \\
\hline F2F & $\begin{array}{l}\text { refers to F2F } \\
\text { Preferencence } \\
\text { throughout the } \\
\text { blended } \\
\text { learning }\end{array}$ & $\begin{array}{l}\text { One student highlighted in one of her earlier } \\
\text { journal entries that she preferred F2F and also later } \\
\text { added, "I think that I still prefer if the course was face- } \\
\text { to-face, but I agree that I've benefited a lot from this } \\
\text { course". }\end{array}$ \\
\hline
\end{tabular}




\begin{tabular}{|c|c|c|}
\hline Category & Item & Sample journal extracts \\
\hline & experience & $\begin{array}{l}\text { Another student wrote, "I prefer face-to-face because } \\
\text { when we attend and discuss in front of the teacher it is } \\
\text { much better...that's because direct contact make you use } \\
\text { all your senses and that leads you to remember and learn } \\
\text { fast." } \\
\text { Few of the students who preferred a F2F learning } \\
\text { experience over the blended learning experience } \\
\text { stated that they missed the personal contact. For } \\
\text { example, this student wrote, "I liked the face to face } \\
\text { because our instructor provides us with real life stories." } \\
\text { Another student wrote, "It was an honour that Dr } \\
\text { [professors name] taught us this course and gave us } \\
\text { some examples from her own experiences which I really } \\
\text { liked." } \\
\text { Others wrote that they preferred the F2F } \\
\text { experience because they were able to get instant } \\
\text { feedback from the teacher. For example one } \\
\text { student wrote, "Body language is most important } \\
\text { because the idea could transfer fast... and we can ask } \\
\text { and have a direct answer." Another student } \\
\text { mentioned that, "the teacher is not in front of us to ask } \\
\text { her directly and the response quickly." }\end{array}$ \\
\hline $\begin{array}{l}\text { Blended } \\
\text { Preference }\end{array}$ & $\begin{array}{l}\text { refers to } \\
\text { blended } \\
\text { learning } \\
\text { preference }\end{array}$ & $\begin{array}{l}\text { One student who enjoyed the blended learning } \\
\text { experience wrote, "Overall, I truly enjoyed this class; } \\
\text { the way that we learnt both in class and online, the way } \\
\text { we presented on blackboard and commented on students } \\
\text { presentations and the way our professor interacted with } \\
\text { us." } \\
\text { Almost all the students who had positive feelings } \\
\text { towards the blended learning experience reasoned } \\
\text { that it helped them become more independent and } \\
\text { responsible. For instance, this student wrote, "I was } \\
\text { amazed that by taking this course, I have learnt and } \\
\text { knew that I can make it by myself and study alone } \\
\text { without a teacher...I have gained an important skill } \\
\text { which is being responsible". Another student stressed } \\
\text { that, "I'm really feeling good and comfortable with the } \\
\text { online experience...from the beginning of this course I I } \\
\text { felt that I'm literally independent and organized." }\end{array}$ \\
\hline $\begin{array}{l}\text { Converted } \\
\text { Preference }\end{array}$ & $\begin{array}{l}\text { refers to } \\
\text { preference of } \\
\text { one specific } \\
\text { class session } \\
\text { (e.g. F2F or } \\
\text { online) at the } \\
\text { beginning of } \\
\text { the semester, } \\
\text { and then a } \\
\text { converted } \\
\text { preference } \\
\text { towards the } \\
\text { end of the } \\
\text { semester }\end{array}$ & $\begin{array}{l}\text { At the beginning of the semester one student } \\
\text { wrote, "unfortunately am not very happy about this } \\
\text { mixed learning course and am concerned about my } \\
\text { grades." Mid semester, she wrote, "I would still } \\
\text { rather learn this information from a face-to-face". } \\
\text { Towards the end of the semester, the same student } \\
\text { wrote, "I think that I am starting to like the online } \\
\text { course thing. } \\
\text { One student said, "when we started the online } \\
\text { learning I was not satisfied but after a few weeks I loved } \\
\text { it..." }\end{array}$ \\
\hline
\end{tabular}


It is important to note that of the students who had converted preferences, $75 \%$ of them had originally preferred F2F and then changed to a blended preference. There was not a significant number of students (25\%) who converted from preferring a blended approach to then preferring a F2F approach.

The data demonstrates that some students had stable and fixed feelings regarding their blended experience throughout the course (either F2F or blended), while others had changing or converting feelings. The students who had positive feelings about their blended learning experience did admit that since it was their first blended learning experience, they felt a little lost and confused but then that feeling changed quickly as the days and weeks passed on. For instance, this student wrote, "In the beginning it was a little bit confused because I didn't know how to use it...Later on I found it much easier that I thought." Another student specifically wrote about her studying skills and how they had been impacted positively as a result of the blended learning experience. She wrote, "From the beginning of the semester I thought that the online part will be hard for me and I may face some difficulties in remembering what to do and when to do it. But I find it a chance to try new thing and try to learn out of it being responsible and organize my life...My behaviour totally changed during the last couple of weeks and I really enjoy marking my tasks or appointment on my calendar which helped me a lot."

On several occasions students who expressed positive or negative feelings towards the blended learning experience made reference to the course content and the teacher. In other words, there seemed to be a relationship between student interaction with the course content and teacher and student feelings towards their blended learning experience. In fact, in the late 80's Moore (1989) spoke about "interactions" that resulted in the transfer of knowledge including identifying interactions between teacher and student, student and student, and student and content.

One can argue that the content of the course as well as the teacher conducting the class may have impacted students' preference for F2F or blended learning. The students indicated that because the topics were appealing and relevant, they were eager to read and learn more. One student wrote, "our topics are appealing and they attract the reader or the student to read more...online experience is better, it forces you to concentrate." Another student wrote, "the topic about children and their developments, thoughts and behaviours is really interesting for me and I would like to learn more about the topic whether it was by online learning or face-to-face lectures." Yet another student wrote, "For this specific topic I would rather learn about it faceto-face because it is a very sad topic and I'd want to hear stories from my classmates about their experiences with them." One student expressed how the course content helped her stay involved. She wrote, "I was amazed by the course content and information that I felt unconsciously involved in such topics". Another student who focused on the relevance of the content in her life stated, "the class experience was very interesting and well-managed. The topics we covered were very important and useful. I believe that the core of this course is highly important to all girls where most of us will be future mothers of new generations." In one final journal entry, this student expressed that, "what I liked most about this course is how useful and fun it is". 
The importance of the content on choosing a preference for learning is also evident in this extract, "I think that it would have been better for a meaningful [F2F] class discussion and debate on several issues with the other students in a verbal discussion." The same student gave an example emphasising that, "the issue of marriages and the increasing divorce rates among the middle age adults in the country would have prompted much heated discussion." One student mentioned that, "I loved the way that my teacher treated us...she was helpful and she tried her best to make this course an easy and interesting course for us". The idea that course content and the instructor may have possibly influenced student F2F or blended learning preference can be noted in the literature. For example, one study established that student satisfaction in online and hybrid [blended] courses depended on course content, student-teacher communications, the use of effective learning tools, and the instructor (Estelami, 2012).

Another observation was that, those who preferred F2F still acknowledged some positive feelings towards the online experience. One student wrote, "There are some skill that developed such as I have been able to organize my time".

Research question 2: What difficulties/challenges did students experience during their blended learning experience?

Regardless of the preferred mode of instruction, a set of difficulties/challenges were identified and these can be seen in Table 2 below. Five varying categories emerged and these included: managing time, technical issues, novelty of the learning experience, added responsibilities, and learning style.

Table 2: Student's difficulties/challenges towards their blended learning experience

\begin{tabular}{|l|l|l|}
\hline Category & Item & Sample Responses \\
\hline $\begin{array}{l}\text { Time } \\
\text { Tanaging }\end{array}$ & $\begin{array}{l}\text { This category refers to } \\
\text { difficulties/challenges } \\
\text { related to time. }\end{array}$ & $\begin{array}{l}\text { One student wrote, "I found it difficult and } \\
\text { challenging to maintain the level of control } \\
\text { required in an online classroom. I always had the } \\
\text { idea that I would get to do the work assigned } \\
\text { eventually, but I ended up wasting a lot of time." } \\
\text { Another student wrote, "it takes us hours to } \\
\text { look for information and to find examples by } \\
\text { ourselves, sometimes we tend to ignore the } \\
\text { online lecture because we can look at it anytime } \\
\text { later. When we do that for several weeks, the } \\
\text { amount of study become more and more, which } \\
\text { is not good." }\end{array}$ \\
\hline
\end{tabular}




\begin{tabular}{|l|l|l|}
\hline Category & Item & Sample Responses \\
\hline $\begin{array}{l}\text { Technical } \\
\text { Issues }\end{array}$ & $\begin{array}{l}\text { This category refers to } \\
\text { difficulties/challenges } \\
\text { related to technical } \\
\text { issues. }\end{array}$ & $\begin{array}{l}\text { One student wrote, "downloading the power } \\
\text { points took a really long time... another challenge } \\
\text { was to be able to hear clearly the sounds of the } \\
\text { girls that were recorded." } \\
\text { A student mentioned, "it's fast, easy to apply } \\
\text { and reach the teacher, but sometimes the } \\
\text { connection is down and you cannot submit your } \\
\text { work on time." }\end{array}$ \\
\hline $\begin{array}{l}\text { Learning } \\
\text { Experience }\end{array}$ & $\begin{array}{l}\text { This category refers to } \\
\text { difficulties/challenges } \\
\text { related to the novelty } \\
\text { of the experience. }\end{array}$ & $\begin{array}{l}\text { A student stated, "I don't have full knowledge } \\
\text { how should I work in the best way of learning } \\
\text { this subject." } \\
\text { Another student stressed, "everything is new } \\
\text { to me and that make me very anxious." }\end{array}$ \\
\hline $\begin{array}{l}\text { Added } \\
\text { Responsibilities }\end{array}$ & $\begin{array}{l}\text { This category refers to } \\
\text { difficulties/challenges } \\
\text { related to student's } \\
\text { added responsibilities } \\
\text { when enrolled in a } \\
\text { blended learning } \\
\text { class. }\end{array}$ & $\begin{array}{l}\text { One student mentioned that, "we faced many } \\
\text { difficulties as getting the main idea...deciding } \\
\text { what to focus on." } \\
\text { Another student wrote, "when I read the } \\
\text { slides, there were some difficult parts that I could } \\
\text { not understand, but I immediately opened the } \\
\text { book and read more about that topic." }\end{array}$ \\
\hline Learning Style & $\begin{array}{l}\text { This category refers to } \\
\text { difficulties/challenges } \\
\text { related to individual } \\
\text { preferences for } \\
\text { learning. }\end{array}$ & $\begin{array}{l}\text { One student specified that, "honestly speaking } \\
\text { I can't depend on myself ... I would rather have } \\
\text { someone explain it to me and I would listen." } \\
\text { One other student also said, "I prefer } \\
\text { listening and writing notes while the instructor } \\
\text { is explaining which makes it easier for me to } \\
\text { focus, understand, and memorize." }\end{array}$ \\
\hline
\end{tabular}

An interesting observation was that the many students who had positive feelings towards their blended learning experience also expressed that the experience made them more independent and responsible. This finding supports the work of Broadbent (2017) and Wang (2003) who showed that technologies not only promote greater student involvement but also generate more individual control and responsibility in the learning process. Still some viewed the added responsibility as a challenge and difficulty as demonstrated in Table 2 above. Even though almost all students discussed difficulties whether they were F2F or blended learning related difficulties, one student stated that she, "did not see any difficulties at all...I just find it very easy and flexible course that I would recommend to all my friends".

In general, this study showed that the participants had mixed feelings about their blended learning experience with the majority preferring F2F learning, although they did not mind some online class sessions because it was a new 
experience, encouraged independency and allowed for flexibility. As the course came to an end, students stressed that the class was the best class they had ever taken and that they would either take another blended learning class and/or recommend this class to their friends and others. As further established in the results, the content of the class showed to impact student's feelings towards the blended learning. The topics discussed in this class (e.g. birth, motherhood, parenting, aging, love and intimacy, etc.) were very relevant to the female students and they openly expressed that they thoroughly enjoyed learning about these topics. Many even wrote about how they were applying what they had learnt from the course (whether through online or F2F means) into their daily lives with their own families and friends. A significant finding of this study is the fact that despite the number of students who preferred a F2F learning experiences and despite the several identified difficulties/challenges, almost all the students mentioned that they enjoyed the blended learning experience and would either recommend the same blended learning class and/or take another blended learning class.

\section{Limitations, Implications, and Future Research}

The two research questions explored in this study led to findings that are suggestive of the need for further investigation. The major contributions of this study is that it is the first attempt to investigate UAE students feelings towards a blended learning class that students were enrolled in, still it is not without limitations. It is worth noting that when students enrolled in the class, they were not aware that it would be a blended class. It would be interesting to see if students would have still enrolled in the class as an elective had they known it was not going to be a typical university F2F class prior to enrolment. The study is gender unbalanced with only female participants. The study is also restricted to one institution and one blended class and therefore results cannot be generalized. The study should be replicated in different learning environments for further investigation.

Similar studies could be carried out with other courses and varying concentrations. One could argue that some courses that are heavy in content may lend themselves better to a blended learning approach. Still it would be interesting to continue investigating students blended learning experiences, so long as there are blended learning opportunities. This can provide valuable information for course designers as they consider current students feedback toward blended learning and make necessary changes that will in turn aim to enhance blended learning experiences.

Implications for pedagogical practice, which could lead to more positive feelings towards blended learning may include providing more opportunities for students to experience blended learning, strengthening practical knowledge related to blended learning and designing and offering courses that have relevant, interesting and applicable content. Informing students of the benefits of the actual blended learning experience and providing all sorts of support (technical, student learning, etc.) throughout the blended learning experience 
may further lead to more positive feeling towards blended learning. As it stands, F2F continues to have a strong impact on student learning.

\section{References}

Al-Mekhlafi, A. (2004). The internet and EFL Teaching: the reactions of UAE secondary school English language teachers. Journal of Language and Teaching, 2(2), 88-113.

Atallah, F., \& Moussa-Inaty, J. (2012). Exploring Faculty and Student Readiness for ELearning in a UAE Public University. In Proceedings of World Conference on ELearning in Corporate, Government, Healthcare, and Higher Education 2012 (pp. 17471754). Chesapeake, VA: AACE. Retrieved from http://www.editlib.org/p/41862.

Atallah, F., \& Moussa-Inaty, J. (2013). Emirati Student Voices on E-learning Readiness. Paper presented at the E-Learn 2013 World Conference on E-Learning in Corporate, Government, Healthcare, and Higher Education, Las Vegas, NV, United States, (October 21-24).

Biju, S.M. (2010). E-learning and blended learning in the Gulf region. in I. Iskander, M., et al. (eds.), Technological Developments in Education and Automation (pp. 7). Springer, New York.

Bonk, C. J., \& Graham, C. R. (2012). The handbook of blended learning: Global perspectives, local designs. John Wiley \& Sons.

Bower, M., Kennedy, G. E., Dalgarno, B., Lee, M. J. W., \& Kenney, J. (2015). Design and implementation factors in blended synchronous learning environments: Outcomes from a cross-case analysis. Computers and Education, 86, 1-17. https://doi.org/10.1016/j.compedu.2015.03.006

Broadbent, J. (2017). Comparing online and blended learner's self-regulated learning strategies and academic performance. The Internet and Higher Education, 33, 24-32. https://doi.org/10.1016/j.iheduc.2017.01.004

Buran, A. \& Evseeva, A. (2015). Prospects of blended learning implementation at technical university. Procedia-Social and Behavioral Sciences, 206(17), 177 -182. https://doi.org/10.1016/j.sbspro.2015.10.049

Daniel, C. (1992). The phenomenology of writing by hand. Intelligent Tutoring Media 3(2/3), 65-74. https:// doi.org/10.1080/14626269209408310

Dziuban, C.D., Hartman, J.L., Moskal, P.D. (2004). Blended Learning. Research Bulletin, 2004 (7). Retrieved from http://net.educause.edu/ir/library/pdf/erb0407.pdf

El Alfy, S., Gómez, J. M., \& Ivanov, D. (2017). Exploring instructors' technology readiness, attitudes and behavioral intentions towards e-learning technologies in Egypt and United Arab Emirates. Education and Information Technologies, 22(5), 2605-2627. https://doi.org/10.1007/s10639-016-9562-1

Estelami, H. (2012). An exploratory study of drivers of student satisfaction and learning experience in hybrid-online and purely online marketing courses. Marketing Education Review, 22(2), 143-155. https://doi.org/10.2753/mer1052-8008220204

Glaser B.G., \& Stauss, A. L. (1967). The Discovery of Grounded Theory, Chicago: Aldine.

Gradel, K., \& Edson, A.J. (2011). Cooperative learning: Smart pedagogy and tools for online and hybrid courses. Journal of Educational Technology Systems, 39(2), 193212. https://doi.org/10.2190/et.39.2.i 
Graham, C. R. (2013). Emerging practice and research in blended learning. In Moore, M.G. (ed) Handbook of distance education ( $3^{\text {rd }}$ ed) (pp. 333-350). New York: Routledge. https://doi.org/10.4324/9780203803738.ch21

Hege, B.A. (2011). The online theology classroom: Strategies for engaging a community of distance learners in a hybrid model of online education. Teaching Theology and Religion, 14(1), 13-20. https://doi.org/10.1111/j.1467-9647.2010.00668.x

Holley, D., \& Oliver, M. (2010). Student engagement and blended learning: Portraits of risk. Computers $\mathcal{E}$ Education, 54(3), 693-700. https://doi.org/10.1016/j.compedu.2009.08.035

Horn, M. B., \& Staker, H. (2014). Blended: Using disruptive innovation to improve schools. John Wiley \& Sons.

Lim, D. H., Morris, M. L., \& Kupritz, V. W. (2014). Online vs. blended learning: Differences in instructional outcomes and learner satisfaction. Journal of Asynchronous Learning Networks, 11(2), 27-42.

Matukhin, D., \& Evseeva, A. (2014). Further Professional Training as a Constituent Part of Continuing Vocational Education. Lecture Notes in Management Science. 2nd International Conference in Humanities, Social Sciences and Global Business Management (ISSGBM 2014), 31,104-109.

Moore, M. (1989). Three types of interaction. The American Journal of Distance Education, 3(2), 1-7. https://doi.org/10.1080/08923648909526659

Moussa-Inaty, J. (2012). Graduate students' e-learning experiences. Unpublished raw data.

Moussa-Inaty, J., \& Atallah, F. (2012). Multimedia use in higher education in the UAE: A cognitive load perspective. Journal of Educational Hypermedia and Multimedia, 21(2), 127-142. Chesapeake, VA: AACE.

Moussa-Inaty, J., Ayres, P., \& Sweller, J. (2012). Improving listening skills in English as a foreign language by reading rather than listening: A cognitive load perspective. Applied Cognitive Psychology, 26, 391-402. https://doi.org/10.1002/acp.1840

Nazarenko, A. (2015). Blended learning vs. traditional learning: What works? (A case study research). Procedia - Social and Behavioral Sciences, 200 (22), 77 -82. https://doi.org/10.1016/j.sbspro.2015.08.018

Oliver, M. \& Trigwell, K. (2005). Can `Blended learning' be redeemed? E-Learning, 2(1), 17-26. https://doi.org/10.2304/elea.2005.2.1.17

Schoepp, K. (2005). Barriers to Technology Integration in a Technology-Rich Environment. Learning and Teaching in Higher Education: Gulf Perspectives, 2 (1), 124.

Singh H, (2003). Building effective blended learning programs. Educational Technology, 43 (6), $51-54$.

Stalker, H., \& Horn, M.B. (2012). Classifying K-12 blended learning. Mountain View, CA: Innosight Institute, Inc. http://www.innosightinstitute.org/innosight/wpcontent/uploads/2012/05/Classifying-K-12-blended-learning2.pdf

Strauss, A., \& Corbin, J. (1990). Basics of qualitative research: Techniques and procedures for developing grounded theory. Thousand Oaks, CA: Sage Publications.

Thorne, K. (2003). Blended Learning: how to integrate online \& traditional learning. London: Kogan. 
Tubaishat, A., \& Lansari, A. (2011). Are Students Ready to Adopt E-Learning? A Preliminary E-readiness Study of a University in the Gulf Region", International Journal of Information and Communication Technology Research, 1(5), 210-215.

Vrazalic, L., MacGregor, R., Behl, D., \& Fitzgerald, J. (2009). E-learning barriers in the United Arab Emirates: Preliminary results from an empirical investigation. Ibima Business Review, 4, 1-7.

Wang, Y.S. (2003). Assessment of learner satisfaction with asynchronous electronic learning systems. Information and Management, 41, 75-86. https://doi.org/10.1016/s0378-7206(03)00028-4

White, C. P., Ramirez, R., Smith, J. G., \& Plonowski, L. (2010). Simultaneous delivery of a F2F course to on-campus and remote off-campus students. TechTrends, 54(4), 3440. https://doi.org/10.1007/s11528-010-0418-Z

Wood, J. (2012). Transformation through journal writing: The art of self-reflection for the helping professions. London: Jessica Kingsley Publishers.

Zhai, X., Gu, J., Liu, H., Liang, J. C., \& Chin-Chung, T. (2017). An Experiential Learning Perspective on Students' Satisfaction Model in a Flipped Classroom Context. Journal of Educational Technology \& Society, 20(1), 198.

Zhu, C. (2017). University student satisfaction and perceived effectiveness of a blended learning course. International Journal of Learning Technology, 12(1), 66-83. https://doi.org/10.1504/IJLT.2017.083996 